\title{
New clues on contamination and perceived quality of second-hand products
}

\section{Novas pistas sobre contaminação e qualidade percebida de produtos usados}

\author{
Júlio César da Costa Júnior Doutorando em Administração (UFPE). Universidade Federal de Pernambuco (UFPE) - Brasil. \\ http://orcid.org/0000-0001-8021-4989 julioccostaj@@gmail.com \\ Leandro da Silva Nascimento Doutorando em Administração (UFRGS). Universidade Federal do Rio Grande do Sul (UFRGS) - \\ http://orcid.org/0000-0003-0981-1718_Brasil. lesnasc@gmail.com \\ Roberta Vanessa Aragão Félix da Silva Mestre em Administração (UFPE). Universidade Federal de Pernambuco (UFPE) - Brasil. \\ http://orcid.org/0000-0003-3056-6980 robertavanessa47@hotmail.com \\ Taciana de Barros Jerônimo Doutora em Engenharia de Produção (UFPE). Professora do Programa de Pós-graduação em \\ http://orcid.org/0000-0003-1643-3030 Administração (UFPE). Universidade Federal de Pernambuco (UFPE) - Brasil. \\ taciana.barros@gmail.com \\ Francisco Vicente Sales Melo Doutor em Administração (UFPE). Professor da Escola de Administração (UFC). Universidade \\ http://orcid.org/0000-0003-0329-668X Federal do Ceará (UFC) - Brasil. vicsmelo@gmail.com \\ Marcos André Mendes Primo PhD em Gestão da Cadeia de Suprimentos (Arizona State University, EUA). Professor do \\ http://orcid.org/0000-0001-8126-9252 Departamento de Ciências Administrativas (UFPE). Universidade Federal de Pernambuco (UFPE) - \\ Brasil.marcos.primo@ufpe.br
}

\begin{abstract}
This study investigates if contamination perception of personal second-hand products by the previous owner can be used as a clue by consumers to evaluate its perceived quality. Data were collected through an electronic survey with 332 Brazilian consumers. Descriptive, correlational, one-way ANOVA and General Linear Model tests were performed to analyze the data. The findings confirm that contamination perception can alter the perceived quality of second-hand products and, therefore, be considered an extrinsic clue. However, this relation can be moderated by other factors such as socioeconomic condition, value consciousness and the source-subject of contamination. Although the purchasing of second-hand products is becoming more popular, few studies aim to understand how consumers evaluate the perceived quality of these items.

Keywords: Contamination perception. Perceived quality. Sustainable consumption. Used product. Consumer behavior.

\section{RESUMO}

Este estudo investiga se a percepção de contaminação de produtos pessoais de segunda mão, usados pelo proprietário anterior, pode ser usada como uma pista pelos consumidores na avaliação de sua qualidade percebida. Os dados foram coletados por meio de pesquisa eletrônica com 332 consumidores brasileiros. Testes descritivos, correlacionais, ANOVA e Modelo Linear Geral foram realizados para analisar os dados. Os resultados confirmam que a percepção de contaminação pode alterar a qualidade percebida de produtos usados e, portanto, ser considerada uma pista extrínseca. No entanto, essa relação pode ser moderada por outros fatores como condição socioeconômica, consciência de valor e o sujeito-fonte da contaminação. Embora a compra de produtos usados esteja se popularizando, poucos estudos buscam compreender como consumidores avaliam a qualidade percebida desses itens.
\end{abstract}

Palavras-chave: Percepção de contaminação. Qualidade percebida. Consumo sustentável. Produtos usados. Comportamento do consumidor. 


\section{INTRODUCTION}

Perceived quality regards the consumer's general evaluation of a good or service through clues or information (Olson \& Jacoby, 1972; Yan, Xiaojun, \& Dong, 2019; Zeithaml, 1988). Some of these clues are inherent or 'intrinsic' to the products, such as physical attributes (Han \& Kwon, 2009). However, more generic and 'extrinsic' clues could also change consumers' perception and influence purchasing propensity (Yan et al., 2019). 'Disgust', for example, is a human emotion associated with aversion or rejection (Fink, Pflugradt, Stierle, \& Exner, 2018; Rozin, Haidt, \& McCauley, 2008). One dimension of this phenomenon is connected to touch by human beings (Haidt, McCauley, \& Rozin, 1994; Rozin et al., 2008). Physical contact between people and objects can trigger 'disgust' and influence the general evaluation of these items (Argo, Dahl, \& Morales, 2006, 2008; Huang, Ackerman, \& Newman, 2008; Morales, Dahl, \& Argo, 2018; Guido, Pino \& Peluso, 2018), which might decrease purchasing propensity, as in the case of second-hand products (Costa Jr., Carvalho Filho, Jerônimo \& Melo, 2019).

However, this influence is not restricted only to perceived quality and may also impact trade-off evaluation between costs and benefits incurred on a purchase based on the perceived value (Biswas \& Roy, 2015; García-Fernández et al., 2018). This construct, wider, is also influenced by other elements, such as the price of the item and consumer's purchasing power (Gallarza, Sil-Saura, Holbrook, 2011; García-Fernández, Gálvez-Ruíz, Fernández-Gavira, Vélez-Colón, Pitts, \& Bernal-Gracía, 2018). Understanding the dynamics of these variables is relevant to second-hand items market, which has stood out due to a higher consumer search for maximizing investment usefulness (Biswas \& Roy, 2015; Papagiannidis, Bourlakis, Alamanos, \& Dennis, 2017). The expectation for lower prices may increase perceived usefulness for this purchase mode (Yan, Bae, \& Xu, 2015). Nevertheless, there is still a stigma attached to the purchasing of second-hand items, seen as some 'disgust' (Guido et al., 2018) and normally associated with poorer consumers (Watson, 2008; Williams, 2002).

This study proposes to investigate if the contamination perception of objects by the previous owner alters the perceived quality of a second-hand product. Based on an electronic survey with 332 Brazilian consumers, it was identified that people consider the contamination a real phenomenon and their quality perception of the used goods influenced by the way they see the older owner. This becomes relevant to the advances in research. With the facilities provided by the internet and the growing popularity of safe sites for buying and selling used products, second-hand markets have evolved into the digital age (Belk, 2013b; Liang \& Liang, 2014). We should also consider the changing consumer behavior regarding conscious consumption, which can help these companies or others that work with reprocessed products to target better their marketing strategy to resolve the negative effects of perceived contamination on used products (Elliott, 2013; Yan et al., 2015). Finally, underlying these observations that can increase current research, is the consumer's assumption as a value maximizer, that is, they want to get the best out of their belongings even after they no longer wish to use the good, with the sale or exchange (Biswas \& Roy, 2015). Therefore, understanding how contamination perception relates to the perceived quality of a used product becomes the key for companies in the sector and consumers to unlock the subjective barriers in this promising market (Yan et al., 2015; Liang \& Liang, 2014); which is something that can be improved through this research findings.

Besides all that related contributions and implications, due to other dimensions that interact with perceived quality to value formation, other possible moderator effects of the price consciousness, value consciousness and consumer's income were also tested on the relation between contamination perception and perceived quality of second-hand products. Thus, implications of the findings for both consumers of used products and companies operating in this market segment are indicated.

\section{THEORETICAL FRAMEWORK}

This section begins with a brief discussion of the main theoretical constructs that support this research. Initially, contamination is addressed from an anthropological perspective. The following are discussed: perceived quality, perceived usefulness, and propensity to purchase. Finally, based on the articulation between constructs, the formulated hypotheses are presented. 


\subsection{Using and 'contaminating' objects}

'Disgust' is a human emotion characterized by repulsiveness and aversion to possible contamination sources (Fink et al., 2018, p. 36; Argo et al., 2008; Guido et al., 2018, p. 105). The stimulus of this type can trigger or awaken strong cognitive and behavioral answers that vary from a feeling of discomfort to total rejection of the contagion target (Guido et al., 2018; Rozin et al., 2008). Many dimensions of 'disgust' were identified and grouped in meta-dimensions by common attributes relative to the trigger of this emotion (Guido et al., 2018). One of them is 'improbable contamination', the focus of this research, that analyses how physical contact of an item with other objects and people changes how a person reacts to it (Guido et al., 2018; Haidt et al., 1994). This is the case of 'interpersonal disgust', related to the personal use of objects by unknown or undesirable people (Guido et al., 2018; Huang et al., 2017; Rozin \& Nemeroff, 1990).

Anthropological studies have already encountered the 'Laws of Sympathetic Magic' (Mauss \& Hubert, 2003; Rozin et al., 1986) and the 'Law of Contagion' (Meigs, 1984). Both perspectives corroborate the idea that a 'target-object' will continue to be influenced by a 'source-subject' even after discontinued physical contact (Meigs, 1984; Rozin \& Nemeroff, 1990). A person, 'magically', transfers his/her personal properties to the target by touch (Mauss \& Hubert, 2003; Rozin et al., 1986; Morales et al., 2018). Perspectives in other fields of study, such as consumer behavior, also suggest a strong link between a person and his/her belongings, which are considered part of their 'extended self' (Belk, 1988, 2013a).

The physical contact of objects with people by touch, therefore, can trigger 'disgust' and influence negatively purchasing intention (Huang et al., 2017; Guido et al., 2018; Yan et al., 2015). The mere suspicion of manipulation by other people tends to trigger rejection to a product, even new ones (Argo et al., 2006; 2008; Morales et al., 2018). When it comes to second-hand products, there is evidence that contamination perception reduces purchasing propensity, but it can be associated to the way how the agent of contagion is seen (Costa et al., 2019; Huang et al., 2017). Contamination by undesirable people is omnipresent (Inozu, Eremsoy, Cicek, \& Ozcanli, 2017; Rozin et al., 2008; Siegal, Fadda, \& Overton, 2011). However, the positive feeling towards the vector of contagion, such as famous people, relatives, and friends, can have an opposite effect (Costa et al., 2019; Belk, 1988, 2013a; Ago et al., 2008).

'Disgust' and contamination perception by a source-subject, therefore, influences consumers behavior: it might alter their general evaluation and purchasing propensity (Costa et al., 2019; Guido et al., 2018; Inozu et al., 2017; Rozin et al., 2008; Huang et al., 2017; Morales et al., 2018). Hence, it is suggested a relation between contamination and perceived quality of second-hand products.

\subsection{Perceived quality, following clues}

Perceived quality concerns consumers' judgment regarding the general excellence or superiority of a good or service (Zeithaml, 1988, p. 3). It is a concept associated with elevated levels of abstraction of an individual and that differs from the objective quality, perspective related to verifiable superiority as to the tangible attributes or predetermined patterns of a product (Han \& Kwon, 2009; Hazen, Boone, Wang, \& Khor, 2017). Perceived quality, therefore, can be understood as an attitude, a consumer's positioning, and has a strong influence over purchasing decision (Parasuraman, Zeithaml, \& Berry, 1985; Yan et al., 2019).

When working with perceived quality, however, it is suggested to distinct characteristics and attributes of a product: the focus on characteristics is usually associated with the possibility of objective measurement by specific techniques; the term attribute, more common in studies of consumer behavior, retains a more subjective dimension of the individual's weighting associated with their needs (MartínezCarrasco, Brugarolas, Martínez-Proveda, Ruiz, \& García-Martínez, 2012).

The perceived quality evaluation by a consumer, in general, happens through 'clues' about the attributes of an item (Olson \& Jacobe, 1972; Yan et al., 2019). These pieces of information can be classified as: intrinsic, physical or inherent characteristics of a product, such as color or texture; and extrinsic, characteristics related to the product and which, even manipulated, could not alter the product itself, such as price, brand, image of the company or country of origin (Martínez-Carrasco et al., 2012; Yan et al., 2019).

Intrinsic clues have a greater influence over quality perception for products consumers have access to (Han \& Kwon, 2009; Olson \& Jacobe, 1972). However, in the case of items that the individual is less familiar 
with, the extrinsic clues, more generic, are the ones who strongly affect the evaluation and purchasing decision (Han \& Kwon, 2009).

While many studies emphasized more tangible or verifiable extrinsic clues, such as package and price, only a few have focused on those intangible or subjective aspects (Olson, 2012; Yan et al., 2019). Thus, there is space for studies to identify other extrinsic and more subjective clues that influence consumers' purchasing decisions (Olson, 2012; Yan et al., 2019).

\subsection{Trade-offs, perceived usefulness and purchasing propensity}

Perceived value is a general consumer evaluation of the usefulness of a product based on the tradeoff between perceived costs and benefits in an exchanging relation (García-Fernández et al., 2018; Han \& Kwon, 2009; Zeithaml, 1988, p. 14). It is a more comprehensive construct that includes, besides perceived quality, other dimensions such as price perception and value consciousness (Beneke, Flyn, Greig, \& Mukaiwa, 2013; Biswas \& Roy, 2015; Pitic, Brad, \& Pitic, 2014). Previous research has shown a positive influence between quality and perceived value (Gallarza et al., 2011; Pitic et al., 2014). Elements that alter an individual quality perception can influence the evaluation of the trade-off related to a product purchasing. Thus, extrinsic clues of quality (Olson, 2012; Yan et al., 2019) should also reverberate on value perception.

Price also retains a strong relation with perceived value and is a complex stimulus that affects consumers differently (Beneke et al., 2013; Khare, Achtani, \& Khattar, 2014; Lichtenstein, Ridgway, \& Netemeyer, 1993). Prices can retract or stimulate consumption because they are related to a sense of risk of loss, especially under a financial bias (Weisstein, Asgari, \& Siew, 2014). A consumer's price consciousness can positively or negatively relativize the assessed costs for their purchasing decision and influence the value perception (Khare et al., 2014).

Economic reasons are recurring in consumer behavior studies regarding purchasing propensity (Hamari, Sjöklint, \& Ukkonen, 2016; Yan et al., 2015). Purchasing power is another element that leads to a reflection of alternative forms of consumption: in the expectation of making the money yield more, lowerincome consumers resort to second-hand product markets (King, 1981; Williams, 2002). However, people start considering these products as inferior when out of poverty, opting for new ones (Watson, 2008). Income, thus, can work as another factor to influence consumer's perceived usefulness in a trading relationship.

Perceived value is a complex abstraction about consumer behavior since it involves idiosyncratic elements, such as price and perceived quality (Gallarza et al., 2011; García-Fernández et al., 2018; Pitic et al., 2014), and economic factors, such as purchasing power (Williams, 2002; Yan et al., 2015). Therefore, the relationship between elements that influence how a consumer evaluates the trade-offs on trade can make a critical determiner of purchase intention (Beneke et al., 2013).

\subsection{Hypotheses and conceptual model}

The confirmation of contamination phenomenon by contact between people and objects in anthropological research (Mauss \& Hubert, 2003; Meigs, 1984; Rozin et al., 1986; Rozin et al., 2008; Rozin \& Nemeroff, 1990) and the strong link between people and their possessions suggested in consumer behavior studies (Belk, 1988, 2013a) show the relevance of this phenomenon to second-hand products market. Since this 'contagion' can trigger 'disgust' and influence the way products are evaluated (Argo et al., 2006; Guido et al., 2018), it is possible to work as a clue for perceived quality (Han \& Kwon, 2009; Yan et al., 2019). Based on this finding, it is proposed that:

Hypothesis 1. Contamination perception can be considered an extrinsic clue on the evaluation of the perceived quality of a second-hand product.

However, the way the vector of the contagion or source-subject is seen can alter the effect of contamination, which will not always be negative, such as the case of family reliques, celebrity items or artisanal (Costa et al., 2019; Inozu et al., 2017; Um \& Kim, 2016; Yan et al., 2015). This leads us to infer that: 
Hypothesis 2a. A positive perception of the source-subject moderates the relation between contamination and perceived quality.

Hypothesis 2b. A negative perception of the source-subject moderates the relation between contamination and perceived quality.

As previously seen, studies relate perceived quality to a more comprehensive construct, the perceived value, which is also influenced by other elements such as price and income, to the evaluation of the usefulness of purchase by the consumer (Gallarza et al., 2011; García-Fernández et al., 2018; Han \& Kwon, 2009; Pitic et al., 2014). Thus, if there is a joint effect of these variants for the perceived value, it is relevant to infer that they could have latent relations. For example, inside the construct perceived quality, the price can be considered an extrinsic clue evaluated by the consumer (Olson \& Jacobe, 1972; Yan et al., 2019). Thus, it is proposed that:

Hypothesis 3a. Price consciousness influences the quality perception of second-hand items.

Hypothesis $3 \mathrm{~b}$. Price consciousness moderates the relation between contamination perception and perceived quality.

It also corroborates with the evidence that consumers wish to maximize the amount invested in a purchase (Biswas \& Roy, 2015; Papagiannidis et al., 2017). A better cost-benefit expectation can lead a consumer to disregard aspects that would usually reduce perceived quality. Therefore, it can be inferred that:

Hypothesis 4a. Value consciousness influences the quality perception of second-hand items.

Hypothesis 4b. Value consciousness moderates the relation between contamination perception and perceived quality.

Lastly, it is important to stress that purchasing power can make people reflect on alternative forms of consumption and resort to the purchase of second-hand items, usually cheaper, to get more usefulness (King, 1981; Williams, 2002; Yan et al., 2015). Based on this finding, it is suggested that:

Hypothesis 5 a. Income influences the quality perception of second-hand items.

Hypothesis $5 \mathrm{~b}$. Income moderates the relation between contamination perception and perceived quality.

The formulated hypotheses are shown in the proposed conceptual model, represented in Figure 1. The next section presents the methodological procedures.

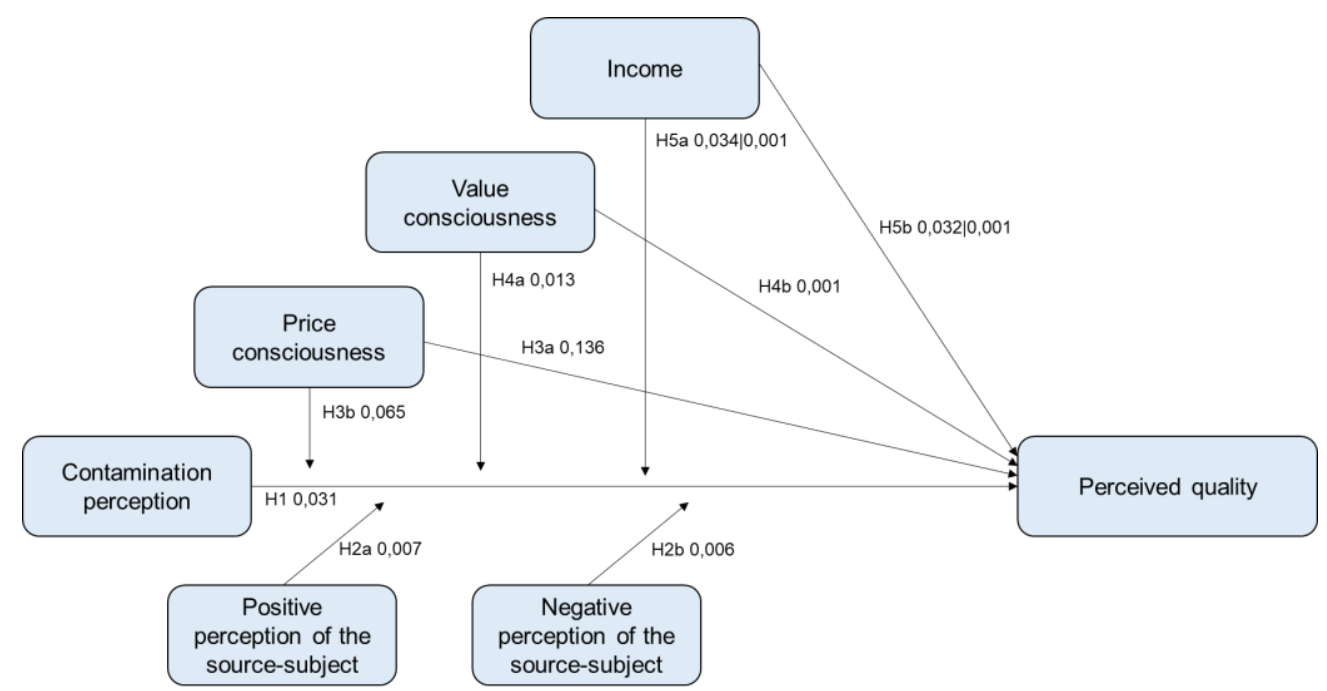

Figure 1. Conceptual model

Source: developed by the authors 


\section{METHOD}

This study is a quantitative descriptive formal, and cross-sectional study whose data collection was made through an electronic survey (Cooper \& Shindler, 2016). The sample, convenience type by accessibility, is formed by 332 valid respondents (Hair Jr., Black, Babin, Anderson, \& Tatham, 2014). The sample is composed of Brazilian consumers, and data were gathered in 2017. The collection instrument was organized in sections that would measure (i) changes in the perceived quality of second-hand items; (ii) contamination perception and influence of source-subject; (iii) value consciousness; (iv) price consciousness; (v) socioeconomic data. The answers were collected on a Likert-type scale of seven points for all constructs, except for the socioeconomic data collected through variable ratio (Cooper \& Schindler, 2016).

Since they do not have a validated scale available, the constructs 'change on the perceived quality of second-hand items', 'contamination' and 'influence of the source-subject' were measured through variables built based on the literature and submitted to pre-tests and tests of validation and reliability, specifically: factor analysis and Cronbach's Alpha (Cooper \& Schindler, 2016; Hair et al., 2014). For the constructs value and price consciousness, instruments already validated were used: 'Price Perception Scales - Dimension Value consciousness' (Lichtenstein et al., 1993); and 'Price Perception Scales - Dimension Price Consciousness' (Lichtenstein et al., 1993).

The reliability and validation of the scales were analyzed through factor analysis and Cronbach's Alpha coefficient (Hair et al., 2014): value consciousness ( $\alpha=0,797$ (var $=60,653 \% \mid K M O=0,815$, Bartlett $=663,212$ with 21 g.l., $p<0,000)$ ); price consciousness ( $\alpha=0,827$ (var=60,107\% $\mid K M O=0,828$, Bartlett $=636,750$ with 10 g.l., $p<0,000)$ ); contamination perception $(\alpha=0,744(\operatorname{var}=57,257 \% \mid K M O=0,726$, Bartlett $=332,954$ with 6 g.l., $p<0,000)$ ); positive influence of source-subject $(a=0,587$ (var $=71,207 \% \mid K M O=0,500$, Bartlett $=65,349$ with 1 g.l., $p<0,000)$ ).

Data analysis was made through the software IBM SPSS Statistics version 25. Besides descriptive and correlational statistical tests, the verification of hypotheses was made through: Pearson's correlation test to verify the significance level among the variables because the sample has a normal distribution; one-way ANOVA, to verify the direct relation among the constructs; and GLM (General Linear Model) to analyze the occurrence of moderations (Hair et al., 2009, 2014).

\section{ANALYSIS AND DISCUSSION OF RESULTS}

This section begins with an analysis of the sample, descriptive data, and some findings of the subjects' perception of the contamination phenomenon. In the sequence, the hypothesis tests and the resulting discussions are presented.

\subsection{Sampling}

Originally, data of 340 respondents was collected, but after outlier's treatment, including analysis through the calculus of Mahalanobis distance (Hair et al., 2014), 8 questionnaires were eliminated. The final 332 samplings are 237 females $(71,4 \%)$ and 95 males $(28,6 \%)$ aged between 18 and 63 years old (average 31 years old). Other socioeconomic data, family and individual incomes, have shown a wide variant: monthly family income varying between $R \$ 600,00$ and $R \$ 120.000,00$, average $R \$ 9,048,11$; monthly individual income varying between $R \$ 0,00$ and $R \$ 70.000,00$ and average of $R \$ 3.115,22$.

Descriptive statistical analysis between the main constructs allows important inferences about the respondents' positioning towards the proposed questions. Only 88 of the respondents perceive second-hand products as inferior and think their purchase is less desirable. For most of them, $73,5 \%$ of the sampling, secondhand products are not necessarily seen as inferior, contrary to what is suggested in previous studies (King, 1981; Watson, 2008; Williams, 2002).

Regarding contamination, about $48,2 \%$ of respondents seem to perceive it strongly: to those parcels of the sample, the contact between people and objects seems to trigger some degree of 'disgust' or aversion (Guido et al., 2018; Rozin et al., 2008;). This evidence corroborates with researches that have confirmed the 
phenomenon of contamination and the relation object-owner (Argo et al., 2006; Belk, 1988, 2013a; Costa et al., 2019; Guido et al., 2018; Rozin et al., 2008).

It was also verified that $34,6 \%$ of respondents positively perceive the contagion by loved people and that $42,2 \%$ have shown higher repulsion to contagion by undesirable people. This confirms that well-evaluated individuals can contaminate an object positively (Belk, 1988, 2013a; Costa et al., 2019; Um \& Kim, 2016) and that contagion by undesirable people is a more generic phenomenon (Inozu et al., 2017; Rozin et al., 2008; Siegal et al., 2011).

Lastly, it was found that $60,5 \%$ of the sample has 'high value consciousness', which confirms the assumption of the consumer as a usefulness maximizer (Biswas \& Roy, 2015; Papagiannidis et al., 2017). As for the price factor and its relevance for purchasing decision, more than half of respondents, $53,3 \%$ of the sample, have shown low sensibility to this variable, which allows questioning previous studies that suggest price is a factor of high relevance to consumers decisions (Beneke et al., 2013; Khare et al., 2014; Lichtenstein et al., 1993).

\subsection{Verification of hypotheses}

To better investigate, the hypotheses tests and analyses of their respective results will be presented in the same formulation order.

4.2.1 Hypothesis 1. Contamination perception can be considered an extrinsic clue on the evaluation of the perceived quality of a second-hand product

This hypothesis was examined through an average test between groups based on the variants 'contamination perception' and 'change on the perceived quality of second-hand products'. From the average of 'contamination perception' the subjects were grouped in individuals with 'low perception' and 'high perception' of the phenomenon. The significant one-way ANOVA test $(F=4,689 ; p<0,05)$ confirms that both constructs are related (Table 1).

However, even though it was verified that the average difference of individuals with high and low contagion perception about the general evaluation of second-hand products is not very high, the statistical significance allows inferring that those who are more sensitive to contamination are more concerned with the purchase of second-hand products (Table 2).

The Pearson correlation test significant between the analyzed variants (Table 3), even indicating a weak correlation, also confirmed that the phenomenon is directly related. As the contamination perception increases, the perceived quality of a second-hand product is altered, and people begin to find problems with their purchase. Data also confirms that most of the people who have high contamination perception did not buy second-hand products (Table 4). At the same time, most of those who have already purchased a secondhand item have low contamination perception.

Thus, data confirm the hypothesis and corroborate the findings suggesting that contamination perception can influence the general evaluation of a consumer about the source-object of contagion (Argo et al., 2006; Guido et al., 2018), and this can influence on purchase decision (Argo et al., 2006; Costa et al., 2019; Han \& Kwon, 2009). 


\begin{tabular}{|c|c|c|c|c|c|c|}
\hline Hypothesis & Between Groups & Sum of Squares & df & $\begin{array}{l}\text { Mean } \\
\text { Square }\end{array}$ & $\mathrm{F}$ & Sig. \\
\hline $\begin{array}{l}\text { Hypothesis } \\
1\end{array}$ & $\begin{array}{l}\text { 'contamination perception' and 'change on the } \\
\text { perceived quality' }\end{array}$ & 5,897 & 1 & 5,897 & 4,689 & 0,03 \\
\hline $\begin{array}{l}\text { Hypothesis } \\
2 \mathrm{a}\end{array}$ & $\begin{array}{l}\text { 'change on the perceived quality of second-hand } \\
\text { product' and 'positive perception of the source- } \\
\text { subject' }\end{array}$ & 6,688 & 1 & 6,688 & 5,329 & 0,02 \\
\hline $\begin{array}{l}\text { Hypothesis } \\
2 b\end{array}$ & $\begin{array}{l}\text { 'contamination perception' and 'negative } \\
\text { perception of the source-subject' }\end{array}$ & 19,845 & 1 & 19,845 & 8,875 & 0 \\
\hline $\begin{array}{l}\text { Hypothesis } \\
3 a\end{array}$ & $\begin{array}{l}\text { 'change on the perceived quality of second-hand } \\
\text { product' and 'price consciousness' }\end{array}$ & 2,833 & 1 & 2,833 & 2,236 & 0,14 \\
\hline $\begin{array}{l}\text { Hypothesis } \\
4 a\end{array}$ & $\begin{array}{l}\text { 'change on the perceived quality of second-hand } \\
\text { product' and 'value consciousness' }\end{array}$ & 13,841 & 1 & 13,841 & 11,22 & 0 \\
\hline Hypothesis & $\begin{array}{l}\text { 'family income' and 'change on the perceived } \\
\text { quality of second-hand product' }\end{array}$ & 13,291 & 4 & 3,323 & 2,666 & 0,03 \\
\hline $\begin{array}{l}\text { Hypothesis } \\
5 a\end{array}$ & $\begin{array}{l}\text { 'individual income' and 'change on the perceived } \\
\text { quality of second-hand product' }\end{array}$ & 21,304 & 3 & 7,101 & 5,829 & 0 \\
\hline
\end{tabular}

Table 1. One-way ANOVA

Source: developed by the authors

\begin{tabular}{lllllllll}
\hline & $\mathrm{N}$ & Average & $\begin{array}{l}\text { Standard } \\
\text { Deviation }\end{array}$ & $\begin{array}{l}\text { Standard } \\
\text { Error }\end{array}$ & $\begin{array}{l}\text { Reliability gap of 95\% for the } \\
\text { average } \\
\text { Lower limit }\end{array}$ & Upper limit & Minimum Maximum \\
\hline $\begin{array}{l}\text { Low } \\
\text { perception }\end{array}$ & 172 & 1,39 & 0,982 & 0,075 & 1,24 & 1,54 & 1 & 7 \\
$\begin{array}{l}\text { High } \\
\text { perception }\end{array}$ & 160 & 1,66 & 1,254 & 0,099 & 1,46 & 1,85 & 1 & 7 \\
\begin{tabular}{l} 
Total \\
\hline
\end{tabular} & 332 & 1,52 & 1,128 & 0,062 & 1,4 & 1,64 & 1 & 7 \\
\hline
\end{tabular}

Table 2. Difference of averages of 'change on the perceived quality of second-hand products' according to 'contamination perception'

Source: developed by the authors

\begin{tabular}{lllll}
\hline Hypothesis & Origin & $\mathrm{N}$ & Sig. (2-tailed) & $\begin{array}{l}\text { Pearson's } \\
\text { Correlation }\end{array}$ \\
\hline Hypothesis 1 & $\begin{array}{l}\text { Change in the evaluation of used } \\
\text { products*Dichotomous contamination } \\
\text { perception }\end{array}$ & 332 & 0,031 &, $118^{*}$ \\
Hypothesis 4a & $\begin{array}{l}\text { Change in the evaluation of used products*Value } \\
\text { Consciousness }\end{array}$ & 332 & 0 &,$- 200^{* *}$ \\
\hline Hypothesis 5a & $\begin{array}{l}\text { Change in the evaluation of used } \\
\text { products*Family income (Categorized) } \\
\text { Change in the evaluation of used } \\
\text { products*Individual income (Categorized) }\end{array}$ & 332 & 0,042 &, $112^{*}$ \\
\hline Hypothesis 5a & 332 & 0,031 &, $118^{*}$ \\
\hline
\end{tabular}

\section{Table 3. Correlation between variables}

Source: developed by the authors

\begin{tabular}{lllll}
\hline & & \multicolumn{2}{l}{ Dichotomous contamination perception } & Total \\
& & Low perception & High perception & \\
\hline $\begin{array}{l}\text { Have you ever bought a used } \\
\text { product? }\end{array}$ & No, I haven't. & 74 & 136 & 210 \\
$\begin{array}{l}\text { Have you ever bought a used } \\
\text { product? }\end{array}$ & Yes, I have. & 98 & 24 & 122 \\
Total & & 172 & 160 & 332 \\
\hline
\end{tabular}

Table 4. Crosstab 'second-hand products purchase' and 'contamination perception'

Source: developed by the authors 
4.2.2 Hypothesis 2a. A positive perception of the source-subject moderates the relation between contamination and perceived quality

Moderating variables can alter the strength or way of the relation between two constructs (Cooper \& Schindler, 2016; Hair et al. 2009). In order to test the finding of the way an individual evaluates a source-subject of contamination can influence the evaluation of the source-target (Costa et al., 2019; Um \& Kim, 2016; Yan et al., 2015) and, therefore, moderate the relation between 'contagion perception' and 'change of the perceived quality' of an item, GLM (General Linear Model) was used. The results ( $F=3,030 ; p<0,05)$, Table 5, confirm the formulated hypothesis.

The one-way ANOVA test (Table 1) between 'positive perception of the source-subject' and 'change of the perceived quality of second-hand items' also shows a relation between these two constructs ( $F=5,329$; $p<0,05)$.

\begin{tabular}{|c|c|c|c|c|c|c|c|}
\hline Hypothesis & Origin & & $\begin{array}{l}\text { Type III Sum of } \\
\text { Squares }\end{array}$ & $\mathrm{gl}$ & $\begin{array}{l}\text { Mean } \\
\text { Square }\end{array}$ & $\mathrm{F}$ & Sig. \\
\hline \multirow{2}{*}{$\begin{array}{l}\text { Hypothesis } \\
2 \mathrm{a}\end{array}$} & $\begin{array}{l}\text { Dichotomous contamination } \\
\text { perception* }\end{array}$ & Hypothesis & 21,38 & 6 & 3,563 & \multirow[t]{2}{*}{3,03} & \multirow[t]{2}{*}{0,007} \\
\hline & $\begin{array}{l}\text { Positive perception of the source- } \\
\text { subject }\end{array}$ & Error & 374,011 & 318 & $1,176^{d}$ & & \\
\hline \multirow{2}{*}{$\begin{array}{l}\text { Hypothesis } \\
2 \mathrm{~b}\end{array}$} & $\begin{array}{l}\text { Dichotomous contamination } \\
\text { perception* }\end{array}$ & Hypothesis & 22,03 & 6 & 3,672 & \multirow[t]{2}{*}{3,072} & \multirow[t]{2}{*}{0,006} \\
\hline & $\begin{array}{l}\text { Negative perception of the source- } \\
\text { subject }\end{array}$ & Error & 380,041 & 318 & $1,195^{d}$ & & \\
\hline \multirow{2}{*}{$\begin{array}{l}\text { Hypothesis } \\
3 \mathrm{~b}\end{array}$} & \multirow{2}{*}{$\begin{array}{l}\text { Dichotomous contamination } \\
\text { perception* } \\
\text { Price consciousness }\end{array}$} & Hypothesis & 12,84 & 5 & 2,568 & \multirow[t]{2}{*}{2,104} & \multirow[t]{2}{*}{0,065} \\
\hline & & Error & 389,39 & 319 & $1,221^{d}$ & & \\
\hline \multirow{2}{*}{$\begin{array}{l}\text { Hypothesis } \\
4 \mathrm{~b}\end{array}$} & \multirow{2}{*}{$\begin{array}{l}\text { Dichotomous contamination } \\
\text { perception* } \\
\text { Value consciousness }\end{array}$} & Hypothesis & 16,286 & 5 & 3,257 & \multirow[t]{2}{*}{2,938} & \multirow[t]{2}{*}{0,013} \\
\hline & & Error & 353,599 & 319 & $1,108^{d}$ & & \\
\hline \multirow{2}{*}{$\begin{array}{l}\text { Hypothesis } \\
5 b\end{array}$} & \multirow{2}{*}{$\begin{array}{l}\text { Dichotomous contamination } \\
\text { perception* } \\
\text { Family income }\end{array}$} & Hypothesis & 46,406 & 23 & 2,018 & \multirow[t]{2}{*}{1,656} & \multirow[t]{2}{*}{0,034} \\
\hline & & Error & 286,326 & 235 & $1,218^{d}$ & & \\
\hline \multirow{2}{*}{$\begin{array}{l}\text { Hypothesis } \\
5 b\end{array}$} & \multirow{2}{*}{$\begin{array}{l}\text { Dichotomous contamination } \\
\text { perception* } \\
\text { Individual income }\end{array}$} & Hypothesis & 59,201 & 24 & 2,467 & \multirow[t]{2}{*}{2,368} & \multirow[t]{2}{*}{0,001} \\
\hline & & Error & 253,079 & 243 & $1,041^{d}$ & & \\
\hline
\end{tabular}

Table 5. Moderating effect between variables

Source: developed by the authors

4.2.3 Hypothesis 2b. A negative perception of the source-subject moderates the relation between contamination and perceived quality

Based on the same theoretical assumptions that sustain 'Hypothesis 2a', it was sought to confirm some effects of the negative perception of the source-subject on the relation between perceived quality and contamination. The $G L M$ test $(F=3,072 ; p<0,05)$, Table 5 , confirms the moderation and the analyzed hypothesis.

The one-way ANOVA test shows averages differences statistically significant $(F=8,875 ; p<0,05)$ between the 'negative perception of the source-subject of contagion' and 'contamination perception' (Table 1). This finding supports the hypothesis and confirms the assumption that the contagion by undesirable people is more generic, universal (Inozu et al., 2017; Rozin et al., 2008; Siegal et al., 2011).

\subsubsection{Hypothesis 3a. Price consciousness influences the quality perception of second-hand items}

Since price is an element used as an extrinsic clue to the evaluation of perceived quality by the individual (Pitic et al., 2014; Yan et al., 2019), it was deduced that consumers' concern with prices, or price consciousness, should influence the perceived quality of second-hand items. However, against previous studies (Beneke et al., 2013; Williams, 2002; Yan et al., 2015), the one-way ANOVA test does not show a statistically significant relation $(F=2,236 ; p>0,05)$ between the average differences of the two constructs (Table 1). Thus, this hypothesis is denied. 
4.2.5 Hypothesis 3b. Price consciousness moderates the relation between contamination perception and perceived quality

Based on the assumption that second-hand items have a lower price (King, 1981; Yan et al., 2015), a greater consumer concern with the price could moderate the relation between 'contamination perception' and 'change on the perceived quality of a second-hand item'. In other words, the lower price could relativize the effects of contamination perception on the evaluation of a product. However, the GLM test $(F=2,104$; $p>0,05$ ), Table 5 , shows that the variable 'price consciousness' does not have a statistically significant influence over the main relation 'contamination perception' and 'change on the perceived quality'.

\subsubsection{Hypothesis 4a. Value consciousness influences the quality perception of second-hand items}

The confirmation that there is a dynamic interaction between the elements used by consumers to abstract about the perceived value on an exchange relation led to the questioning of a possible direct relationship between these elements. This is the case of the relation between 'value consciousness' and 'change on the perceived quality of second-hand items', hypothesis confirmed by one-way ANOVA test ( $F=$ $11,221 ; p<0,05)$, Table 1.

The Pearson's correlation coefficient (Table 3) also supports the acceptance of the hypothesis due to the negative correlation between the constructs: the higher value consciousness implies in a lower change of quality perception of a second-hand item and, therefore, that the item is considered inferior.

4.2.7 Hypothesis $4 b$. Value consciousness moderates the relation between contamination perception and perceived quality

Based on the assumption of the consumer as a maximizer of usefulness (Biswas \& Roy, 2015), it is supposed that the relation between 'contamination perception' and 'change on the perceived quality of a second-hand item' can be moderated by 'value consciousness'. The statistically significant GLM test ( $F=2,938$; $\mathrm{p}<0,05$ ) between these variables, Table 5 , confirms the hypothesis and previous studies in which its formulation was based (Biswas \& Roy, 2015; García-Fernández et al., 2018; Papagiannidis et al., 2017; Pitic et al., 2014).

\subsubsection{Hypothesis 5a. Income influences the quality perception of second-hand items}

Based on the assumption that the purchase of second-hand items is associated to people with low purchasing power (King, 2008; Watson, 2008; William, 2002; Yan et al., 2015), it was analyzed, through individual and family incomes, if the socioeconomic status influences the change on perceived quality of second-hand items. The one-way ANOVA tests between the variable 'change on the perceived quality' and the variables 'family income' $(F=2,666 ; p<0,05)$ and 'individual income' $(F=5,829 ; p<0,05)$, both categorized in groups from the average, confirmed the formulated hypothesis (Table 1).

The statistically significant correlation between individual and family incomes and the variable 'change on the perceived quality' suggests that individuals with high income apparently see second-hand items as lower quality (Table 3). However, the highest concentration of subjects whose quality of second-hand products is altered and perceived as inferior does not occur in higher income ranges.

\subsubsection{Hypothesis $5 b$. Income moderates the relation between contamination perception and perceived quality}

Due to the perspective that the socioeconomic status alters the perceived quality of second-hand items (Hypothesis 5a) and the assumption that low incomes can relativize the evaluations of certain attributes of a product (William, 2002; Watson, 2008), the relation between contamination perception and change on the quality of second-hand items is moderated by family and individual incomes was tested. The GLM tests, Table 5 confirmed that incomes alter the strength or form of the relation between these two main constructs. 


\section{CONCLUSIONS}

Perceived quality is a complex abstraction about the general evaluation of a product by a consumer. This research has shown that there are subjective dimensions that influence the purchasing decisions in the case of second-hand products. We show that the contamination perception of a target-object by a sourcesubject can alter the perceived quality of a second-hand product and, therefore, can be considered an extrinsic clue used by consumers for evaluation and purchase decisions. In doing so, we reach the main objective of this research.

Also, we highlighted some obstacles to the purchase of second-hand products that go beyond rationality regarding consumer behavior. An example is the influence of the evaluation of the former owner image on the contamination perception. Although this is a finding already considered in the literature, the effects of this on perceived quality have not been directly addressed statistically and may indicate new insights for companies that manage sales platforms of used products.

As a possible action to mitigate negative effects associated with an eventual bad evaluation of the former owner, our analyses let suggest that such second-hand products sites should enable communication between sellers and potential buyers. By emphasizing the subjective side of these relationships, it is possible to explore the affective value underlying these exchange relationships due to people's eventual attachment to their goods, and so, overcome the main focus on the utility associated with the purchase of these products. Also, we believe that it could enhance the buyer's perception of value by including him in a broader network of trade relationships.

Another contribution was the confirmation of factors that influence the perceived usefulness in a trade relationship could influence one another mutually: this includes income and value consciousness effects on the perceived quality. However, contrary to previous research, our findings suggest that the price seems not to have much relevance to purchasing decision anymore, at least in second-hand products. Due to this finding, we recommend the focus on this issue as a theme for future research.

Overall, our results can be particularly useful for companies operating in the used product business, such as the popular websites that provide a channel for people to sell used objects that they no longer use. Aware of the effects of the perception of contamination for the perceived quality of used products, advertising actions can be directed to promote an apology for conscious consumption as a way to resolve its negative effects. Furthermore, given the urgency for ecological alternatives to the main production and consumption channels (e.g. Circular Economy), this evidence can help marketers better understand the obstacles to lateral product cycling: the purchase and sale of products among consumers. In this sense, another fruitful path for future research is the integration of these results with Transformative Consumer Research, which aims to help improve people's lives as consumers. We believe that this focus can help economically vulnerable consumers to have a better relationship with their low-price possibilities of purchase, like second-hand products.

Other possibilities are related to research on reverse logistics, conscious consumption, and purchase decision. About logistics, we can explore the architecture of a "consumer-to-consumer" channel of trade and the active role of the final consumer to the reentrance of items in the reverse flow of products after their consumption. Conscious consumption is another trendy topic in consumer behavior, specifically regarding the question of contamination perception. Although the positive attitude of many individuals towards the potential effects of the purchase of used products over the environment is well known, this concern may not lead to actual conscious consumption behavior. So, not always the conscious consumption or even the perception of value in a trade relation will lead to the consumer's expected purchase decision; this is a complex question that should continue to be explored in the case of second-hand products.

We also suggested for future investigations, the complex relationship between income and quality perception of second-hand items. Our analyses found a relation between these constructs; however, this partially diverges from evidence found in the literature that higher aversion and tolerance to second-hand products are found, respectively, on the extremes of higher and lower incomes.

Of course, all these contributions, as said, reverberate directly to practitioners. In summary: (i) how they explore subjective aspects in exchange relations to mitigate the negative effects of contamination; (ii) how to explore the creation of links between used product buyers and sellers as a means of adding value; (iii) 
formulation of marketing strategies that emphasize mitigating aspects of the effects of the perception of contamination on the perceived quality, such as awareness of value and awareness of consumption; (iv) create more proactive channels to enable $\mathrm{C} 2 \mathrm{C}$ businesses; $(\mathrm{v})$ situating the final consumer as a potential channel and support point for reverse logistics, among others.

Finally, some limitations of this study refer to the convenience type sample and a great variety of socioeconomic attributes like age and income, which may make it difficult to identify a significant correlation between these and other variables; and to the subjectivity inherent to the measured constructs such as value consciousness, altered perceived quality and contamination perception. In this sense, future studies may deepen the understanding of contamination and quality perception on purchase of second-hand products in other countries, because cultural, economic, social, and political variations may demonstrate results that can be complementary or contrasting to those presented here.

\section{REFERENCES}

Argo J. J., Dahl, D. W., \& Morales, A. C. (2006). Consumer contamination: how consumers react to products touched by others. Journal of Marketing, 70, 81-94. http://dx.doi.org/10.1509/jmkg.70.2.81

Argo J. J., Dahl, D. W., \& Morales, A. C. (2008). Positive consumer contagion: responses to attractive others in a retail contexto. Journal of Marketing Research, 45(6), 690-701. https://doi.org/10.1509/jmkr.45.6.690

Belk, R. W. (1988). Possessions and the extended self. The Journal of Consumer Research, 15(2), 139-168. https://doi.org/10.1086/209154

Belk R. W. (2013a). Extended self in a digital world. The Journal of Consumer Research, 40(3), 477-500. http://dx.doi.org/10.1086/671052

Belk R. W. (2013b). You are what you can access: sharing and collaborative consumption online. The Journal of Business Research, 67, 1585-1600. http://dx.doi.org/10.1016/j.jbusres.2013.10.001

Beneke, J., Flyn, R., Greig, T., \& Mukaiwa, M. (2013). The influence of perceived product quality, relative price and risk on customer value and willingness to buy: a study of private label merchandise. Journal of Product \& Brand Management, 22(3), 218-228. http://dx.doi.org/10.1108/JPBM-02-2013-0262

Biswas, A., \& Roy, M. (2015). Leveraging factors for sustained green consumption behavior based on consumption value perceptions: testing the structural model. Journal of Cleaner Production, 95, 332-340. https://doi.org/10.1016/j.jclepro.2015.02.042

Cooper, D. R., \& Schindler, P. S. (2016). Métodos de Pesquisa em Administração. Porto Alegre: AMGH.

Costa, Jr., J. C., Carvalho, Filho, P. M. B., Jerônimo, T. B., \& Melo, F. V. S. (2019). Overcoming contamination and purchasing used products. Brazilian Journal of Marketing, 19(1), 132-146. https://doi.org/10.5585/remark.v18i1.3930

Elliott, R. (2013). The taste for green: the possibilities and dynamics of status differentiation through "green" consumption. Poetics, 41, 294-322. https://doi.org/10.1016/j.poetic.2013.03.003

Fink, J., Pflugradt, E., Stierle, C., \& Exner, C. (2018). Changing disgust through imagery rescripting and cognitive reappraisal in contamination-based obcessive-compulsive disorder. Journal of Anxiety Disorders, 54, 36-48. https://doi.org/10.1016/j.janxdis.2018.01.002

Gallarza, M.G., Gil-Saura, I., \& Holbrook, M.B. (2011). The value of value: Further excursions on the meaning and role of customer value. Journal of Consumer Behaviour, 10, 179-191. https://doi.org/10.1002/cb.328

García-Fernández, J., Gálvez-Ruíz, P., Fernández-Gavira, J., Vélez-Colón, L., Pitts, B., \& Bernal-Gracía, A. (2018). The effects of service convenience and perceived quality on perceived value, satisfaction and loyalty in low-cost fitness centers. Sport Management Review, 21, 250-262.

http://dx.doi.org/10.1016/j.smr.2017.07.003 
Guido, G., Pino, G., \& Peluso, A.M. (2018). The impact of disgust on consumers' purchase intentions: an empirical assessment. Journal of Consumer Marketing, 35(1), 105-115. https://doi.org/10.1108/JCM-04$\underline{2016-1786}$

Haidt, J., McCauley, C., \& Rozin, P. (1994). Individual differences in sensitivity to disgust: a scale sampling seven domains of disgust elicitors. Personality and Individual Differences, 16(5), 701-713. https://doi.org/10.1006/jrpe.1999.2251

Hair, Jr., J. F., Black, W. C., Babin, B. J., Anderson, R. E., \& Tatham, R. L. (2009). Análise Multivariada de Dados. Porto Alegre: Bookman.

Hair, Jr., J. F., Wolfinbarger, M., Ortinau, D. J., \& Bush, R. P. (2014). Fundamentos de Pesquisa de Marketing. Porto Alegre: AMGH.

Hamari, J., Sjöklint, M., \& Ukkonen, A. (2016). The sharing economy: why people participate in collaborative consumption. Journal of the Association for Information Science and Technology, 67(9), 2047-2059. http://doi.org/10.1002/asi.23552

Han, J.-W., \& Kwon, H. H. (2009). The mediating effect of perceived quality between extrinsic cues and perceived value in ski products. International Journal of Sports Marketing and Sponsorships, 10(4), 18-32. https://doi.org/10.1108/IJSMS-10-04-2009-B003

Hazen, B. T., Boone, C. A., Wang, Y., \& Khor, K. S. (2017). Perceived quality of remanufactured products: construct and measure development. Journal of Cleaner Production, 142(2), 716-726. http://doi.org/10.1016/.j.jclepro.2016.05.099

Huang, J. Y., Ackerman, J. M., \& Newman, G. E. (2008). Catching (up with) magical contagion: a review of contagion effects in consumer contexts. Journal of the Association for Consumer Research, 2(4), 430-443. http://dx.doi.org/10.1086/693533

Khare, A., Achtani, D., \& Khattar, M. (2014). Influence of price perception and shopping motives on Indian consumers' attitude towards retailer promotions in malls. Asian Pacific Journal of Marketing and Logistics, 30(2), 234-245. http://doi.org/10.1108/APJML-09-2013-0097

King, M. (1981). Disneyland and Walt Disney World: traditional values in futuristic form. Journal of Popular Culture, 15(1), 116-140. http://doi.org/10.1108/APJML-09-2013-0097

Inozu, M., Eremsoy, E., Cicek, N. M., \& Ozcanli, F. (2017). The association of scrupulosity with disgust propensity and contamination based obsessive-compulsive symptoms: an experimental investigation using highly scrupulous muslims. Journal of Obsessive-Compulsive and Related Disorders, 15, 43-51. https://doi.org/10.1016/j.jocrd.2017.08.004

Liang, C. C., \& Liang, W. Y. (2014). Efficient communication architecture for the C2C agent. Computer Standards \& Interfaces, 36, 641-647. https://doi.org/10.1016/j.csi.2013.09.001

Lichtenstein, D. R., Ridgway, N. M., \& Netemeyer, R. G. (1993). Price perceptions and consumer shopping behavior: a field study. Journal of Marketing Research, 30(2), 234-245. http://doi.org/10.2307/3172830

Martínez-Carrasco, L., Brugarolas, M., Martínez-Proveda, A., Ruiz, J. J., \& García-Martínez, S. (2012). Modelling perceived quality of tomato by structural equation analysis. British Food Journal, 114(10), 1414-1431. http://doi.org/10.1108/00070701211262993

Mauss, M., \& Hubert, H. (2003). Esboço de uma teoria geral da magia. In M. Mauss (Ed.), Sociologia e Antropologia (pp. 47-181). São Paulo: Cosac \& Naify.

Meigs, A. S. (1984). Food, sex and pollution: a new Guinea Religion. New Jersey: Rutgers Univisity Press.

Morales, A. C., Dahl, D. W., \& Argo, J. J. (2018). Amending the Law of Contagion: a general theory of property transference. Journal of the Association for Consumer Research, 3(4). http://doi.org/10.1086/698907 
Olson, J. C., \& Jacoby, J. (1972). Cue utilization in the quality perception process. In: Proceedings of the Third Annual Conference of the Association for Consumer Research, Chicago, IL, USA, 167-179.

Olson, E. L. (2012). Supplier inferences to enhance private label perceptions. Journal of Business Research, 65(1), 100-105. http://doi.org/10.1016/j.jbusres.2011.02.004

Papagiannidis, S., Bourlakis, M., Alamanos, E., \& Dennis, C. (2017). Preferences of smart shopping channels and their impact on perceived wellbeing and social inclusion. Computer in Human Behavior, 77, 396-405. https://doi.org/10.1016/j.chb.2017.04.029

Parasuraman, A., Zeithaml, V., \& Berry, L. (1985). A conceptual model of service quality and its implications for future research. Journal of Marketing, 49(4), 41-50. https://doi.org/10.1177/002224298504900403

Pitic, L., Brad, S., \& Pitic, D. (2014). Study on perceived quality and perceived fair price. Procedia Economics and Finance, 15, 1304-1309. http://doi.org/10.1016/S2212-5671(14)00592-9

Rozin, P., Haidt, J., \& McCauley, C.R. (2008). Disgust. In M. Lewis, J.M. Haviland-Jones, \& L.F. Barret (Eds.). Handbook of Emotions (pp. 757-776). New York: Guilford Press.

Rozin, P., Millman, L., \& Nemeroff, C. (1986). Operation of the laws of sympathetic magic in disgust and other domains. Journal of Personality and Social Psychology, 50(4), 703-712. https://doi.org/10.1037/0022$\underline{3514.50 .4 .703}$

Rozin, P., \& Nemeroff, C. (1990). The laws of sympathetic magic: a psychological analysis of similarity and contagion. In J.W. Stingler, R.A. Shweder, \& G. Herdt (Eds.). Cultural Psychology. Essays on comparative human development (pp. 205-232). Cambridge: Cambridge University Press.

Siegal, M., Fadda, R., \& Overton, P. G. (2011). Contamination sensitivity and the development of diseaseavoidant behavior. Philosophical Transactions of the Royal Society B, 366, 3427-3432.

https://doi.org/10.1098/rstb.2011.0036

Um, N.-H., \& Kim, S. (2016). Determinants for effects of celebrity negative information: when to terminate a relationship with a celebrity endorser in trouble?. Psychology \& Marketing, 33(10), 864-874. https://doi.org/10.1002/mar.20923

Watson, M. (2008). A review of literature and research on public attitudes, perceptions and behavior relating to remanufactured, repaired and reused products. Report for the Centre for Remanufacturing and Reuse/2008, Centre for Remanufacturing \& Reuse, The University of Sheffield, Sheffield, UK.

Weisstein, F. L., Asgari, M., \& Siew, S.-W. (2014). Price presentation effects on green purchase intentions. Journal of Product \& Brand Management, 23(3), 230-239. http://doi.org/10.1108/JPBM-06-2013-0324

Williams, C. C. (2002). Why do people use alternative retail channels? Some case-study evidence from two English cities. Urban Studies, 39(10), 1897-1910. https://doi.org/10.1080/0042098022000003019

Yan, R.-N., Bae, S.Y., \& Xu, H. (2015). Second-hand clothing shopping among college students: the role of psychographic characteristics. Young Consumers, 16(1), 85-98. https://doi.org/10.1108/YC-02-2014-00429

Yan, L., Xiaojun, F., Li, J., \& Dong, X. (2019). Extrinsic cues, perceived quality, and purchase intention for private labels: Evidence from the Chinese Market. Asia Pacific Journal of Marketing and Logistics, 31(3), 714-727. https://doi.org/10.1108/APJML-08-2017-0176

Zeithaml, V.A. (1988). Consumer perceptions of price, quality, and value: a means-end model and synthesis of evidence. Journal of Marketing, 52, 2-22. http://doi.org/10.2307/1251446 